\title{
Article \\ Efficient Molybdenum Hydrazonato Epoxidation Catalysts Operating under Green Chemistry Conditions: Water vs. Decane Competition
}

\author{
Silvija Mrkonja ${ }^{1}$, Edi Topić ${ }^{1}$, Mirna Mandarić ${ }^{1}$, Dominique Agustin ${ }^{2,3}$ (이 and Jana Pisk ${ }^{1, *(1)}$ \\ 1 Faculty of Science, Department of Chemistry, University of Zagreb, Horvatovac 102a, 10000 Zagreb, Croatia; \\ silvija.mrkonja@chem.pmf.hr (S.M.); edi.topic@chem.pmf.hr (E.T.); mirna.mandaric@chem.pmf.hr (M.M.) \\ 2 IUT P. Sabatier, Department of Chemistry, University of Toulouse, Av. G. Pompidou, BP20258, CEDEX, \\ 81104 Castres, France; dominique.agustin@iut-tlse3.fr \\ 3 CNRS, LCC (Laboratoire de Chimie de Coordination), 205 route de Narbonne, BP44099, CEDEX 4, \\ 31077 Toulouse, France \\ * Correspondence: jana.pisk@chem.pmf.hr; Tel.: +385-1-4606-350
}

Citation: Mrkonja, S.; Topić, E.; Mandarić, M.; Agustin, D.; Pisk, J. Efficient Molybdenum Hydrazonato Epoxidation Catalysts Operating under Green Chemistry Conditions: Water vs. Decane Competition. Catalysts 2021, 11, 756. https:// doi.org/10.3390/catal11070756

Academic Editor: Carla D. Nunes

Received: 4 June 2021

Accepted: 19 June 2021

Published: 22 June 2021

Publisher's Note: MDPI stays neutral with regard to jurisdictional claims in published maps and institutional affiliations.

Copyright: (c) 2021 by the authors. Licensee MDPI, Basel, Switzerland. This article is an open access article distributed under the terms and conditions of the Creative Commons Attribution (CC BY) license (https:// creativecommons.org/licenses/by/ $4.0 /)$.

\begin{abstract}
Molybdenum compounds containing benzaldehyde-based hydrazones were obtained. The reaction in $\mathrm{MeOH}$ resulted with monomeric Mo complexes, $\left[\mathrm{MoO}_{2}(\mathrm{~L})(\mathrm{MeOH})\right]$, while the reaction in dichloromethane $(\mathrm{DCM})$ provided oligomeric complexes, $\left[\mathrm{MoO}_{2}(\mathrm{~L})\right]_{\mathrm{n}}$. The solid-state structures of the obtained compounds were investigated through Infrared Spectroscopy - Attenuated Total Reflection (IR-ATR), Thermogravimetric analysis (TGA), and via X-ray diffraction. The prepared molybdenum species were employed as cyclooctene epoxidation catalysts. TBHP (tert-butylhydroperoxide) in water and TBHP in decane were employed and compared as oxidants, with $0.25 \mathrm{~mol} \%$ [Mo]. The catalyst activity and selectivity towards epoxide is $>90 \%$ for all the reactions. The results have been linked to theoretical calculations, showing the importance of the first step, i.e., the transformation of $\left[\mathrm{MoO}_{2}(\mathrm{~L})(\mathrm{MeOH})\right]$ into the pentacoordinate $\left[\mathrm{MoO}_{2}(\mathrm{~L})\right]$.
\end{abstract}

Keywords: molybdenum; aroylhydrazone; epoxidation; catalysis; organic solvent-free process; TBHP in decane; TBHP in water; DFT calculations

\section{Introduction}

Epoxides are known to be crucial raw materials widely employed in everyday life. One of the main routes for epoxide production is alkene epoxidation, where alkene is converted into epoxide when subjected to a peroxy acid of general formula $\mathrm{RCOOOH}$. Peroxy acids usually applied are peroxy trifluoroacetic acid, peroxyacetic acid, and metachloroperoxybenzoic acid [1]. From an environmental point of view, the introduced pathway bears severe drawbacks (i.e., long and tedious post-treatment and high generation of waste). Nowadays, TBHP (tert-butylhydroperoxide) makes a significant contribution, especially at the industrial scale, as it produces less waste and the byproduct formed upon the reaction can be reused [2,3]. For metal-catalyzed epoxidations with alkyl hydroperoxides $(\mathrm{ROOH})$ used as oxidants, highly active catalysts show Lewis acidity and low oxidation potentials in their highest oxidation states. Their relative activity is usually $\mathrm{Mo}>\mathrm{W}>\mathrm{Ti} \sim \mathrm{V}$. The commercially available molybdenum compounds $\left[\mathrm{MoO}_{2}(\mathrm{acac})_{2}\right]\left(\mathrm{acac}=\mathrm{C}_{5} \mathrm{H}_{7} \mathrm{O}_{2}\right)$ and $\mathrm{Mo}(\mathrm{CO})_{6}$ have been tested as very active and selective epoxidation catalysts [4,5]. Within the development of the research in this area, the systems containing $\left\{\mathrm{MoO}_{2}\right\}^{2+}$ core and coordinated Schiff base ligand showed a great epoxidation potential [6,7]. In most of the reactions dealing with such Mo complexes, 1,2-dichloroethane (DCE) or other chlorinated solvents were the best solvents for the reaction. Focus is also done on the minimization or complete elimination of the solvents used as reaction media, following the green chemistry policies and solvent-less chemistry. For instance, the Montreal Protocol on substances depleting the ozone layer is a global agreement to protect the Earth's ozone layer by phasing 
out the chemicals that diminish it. Regarding it carbon tetrachloride was substituted in 1989 by the halogenated solvents chloroform and dichloromethane (DCM) [8]. Since DCM today is recognized to have cancerogenic properties and to deplete the ozone layer, the idea is to replace DCM with other, less harmful solvents [9]. Due to it, modern solvent selection tools, driven by Pfizer and Sanofi, classify water and alcohol as preferred and recommended solvents [10].

In the proposed quest, our research follow-up was to obtain efficient molybdenum epoxidation catalysts containing benzaldehyde-based hydrazones (Scheme 1). The choice of ligands lies in the fact that the similar molybdenum complexes showed good activity and were classified as efficient catalytic systems [11-13]. In the presented research, the stress was on the use of 2-hydroxy-benzhydrazide derivatives, that could provide catalytically active molybdenum complexes. In addition, the presence/position and position of the methoxy group on the ligand has been a studied factor, to see its influence on the catalytic activity. The catalytic results have been compared to theoretical calculations, linking the activity to a mechanistic study.

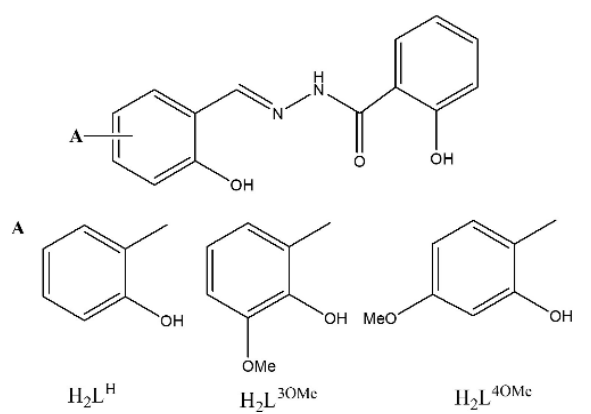

Scheme 1. Ligands $\mathrm{H}_{2} \mathrm{~L}^{\mathrm{H}}$, 3OMe and 4OMe employed for the complex and catalyst preparation.

\section{Results and Discussion}

\subsection{Catalysts Preparation and Solid-State Characterization}

All the ligands were prepared by the conventional procedure, in methanol or ethanol. With the intention of synthetic improvement, a solvent-less technique was applied as well. The stoichiometric amounts of appropriate aldehyde (salicylaldehyde, 3-methoxyor 4 methoxy-salicylaldehyde, and 2-hydroxy-benzhydrazide were employed, and liquid assisted grinding (LAG) was applied. The existence of the same ligands, prepared by different routes, was confirmed by IR-ATR and PXRD.

The mixture of equimolar amounts of $\left[\mathrm{MoO}_{2}(\mathrm{acac})_{2}\right]$ and ligand, $\mathrm{H}_{2} \mathrm{~L}^{\mathrm{H}}, \mathrm{H}_{2} \mathrm{~L}^{3 \mathrm{OMe}}$, or $\mathrm{H}_{2} \mathrm{~L}^{4 \mathrm{OMe}}$, provided oligomeric complexes in $\mathrm{DCM},\left[\mathrm{MoO}_{2}\left(\mathrm{~L}^{\mathrm{H}}\right)\right]_{\mathrm{n}},\left[\mathrm{MoO}_{2}\left(\mathrm{~L}^{3 \mathrm{OMe}}\right)\right]_{\mathrm{n}}$, and $\left[\mathrm{MoO}_{2}\left(\mathrm{~L}^{4 \mathrm{OMe}}\right)\right]_{\mathrm{n}}$, while monomeric complexes were isolated from $\mathrm{MeOH},\left[\mathrm{MoO}_{2}\left(\mathrm{~L}^{\mathrm{H}}\right)(\mathrm{MeOH}]\right.$, $\left[\mathrm{MoO}_{2}\left(\mathrm{~L}^{3 \mathrm{OMe}}\right)(\mathrm{MeOH})\right]$, and $\left[\mathrm{MoO}_{2}\left(\mathrm{~L}^{4 \mathrm{OMe}}\right)(\mathrm{MeOH})\right]$ (Scheme 2$)$. Each oligomeric complex could be transformed into the monomeric one by heating the complex in methanol and vice versa.

Oligomeric complexes $\left[\mathrm{MoO}_{2} \mathrm{~L}\right]_{\mathrm{n}}$ were easily distinguished from monomeric by the simple comparison of the IR-ATR spectra. The wide absorption band at around $810 \mathrm{~cm}^{-1}$, attributed to $\mathrm{Mo}=\mathrm{O} \cdots$ Mo polymerization mode, vanished in the spectra of the corresponding monomeric complex $\left[\mathrm{MoO}_{2} \mathrm{~L}(\mathrm{MeOH})\right][14,15]$. The appearance of the stretching frequencies characteristic of $v\left(\mathrm{MoO}_{2}\right)$ (found at $940 \mathrm{~cm}^{-1}, 917 \mathrm{~cm}^{-1}$ and $900 \mathrm{~cm}^{-1}$ ) characterized unambiguously the monomeric compounds (Supplementary Materials Figure S1). In addition, the bands typical for bands characterizing the $\mathrm{N}-\mathrm{H}$ and $\mathrm{C}=\mathrm{O}$ groups of the ligand in the neutral form, at around $3190 \mathrm{~cm}^{-1}$ and $1662 \mathrm{~cm}^{-1}$, respectively) are absent in the spectra of molybdenum complexes, implying keto-enol tautomerization and ligand coordination to the molybdenum center through deprotonated oxygen atoms. Addition support for this hypothesis is a band at $1345 \mathrm{~cm}^{-1}$. The vibration band belonging to $\mathrm{C}=\mathrm{N}_{\text {imine }}$ of the neutral ligands at $1650 \mathrm{~cm}^{-1}$ was shifted to $1625 \mathrm{~cm}^{-1}$ in the spectra of the molybdenum complexes. 


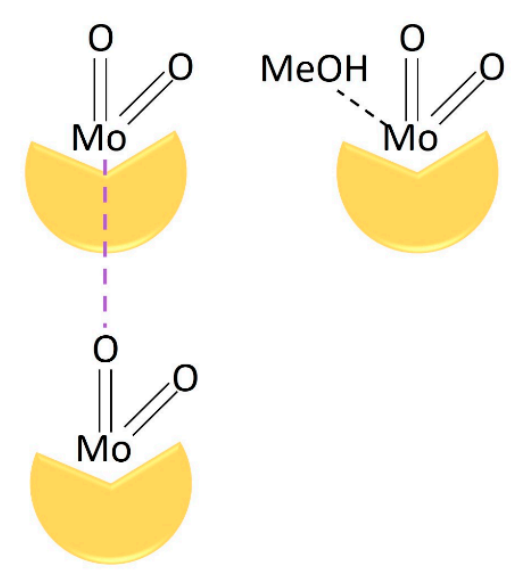

Scheme 2. Presentation of the oligomeric Mo complexes (left) and monomeric Mo complexes (right). Ligands $\mathrm{H}_{2} \mathrm{~L}^{\mathrm{H}}$, 3OMe and 4OMe employed for the catalyst preparation are presented with the yellow partial circle. Polymerization mode through a terminal oxygen atom, occurring in the oligomeric complexes, is presented by the dashed purple line.

The thermal analysis of the monomeric complexes, $\left[\mathrm{MoO}_{2}\left(\mathrm{~L}^{\mathrm{H}}\right)(\mathrm{MeOH}],\left[\mathrm{MoO}_{2}\left(\mathrm{~L}^{3 \mathrm{OMe}}\right)\right.\right.$ $(\mathrm{MeOH})]$, and $\left[\mathrm{MoO}_{2}\left(\mathrm{~L}^{4 \mathrm{OMe}}\right)(\mathrm{MeOH})\right]$, showed a two-step thermal decomposition. The first step, within the range $125-152{ }^{\circ} \mathrm{C}$ for $\left[\mathrm{MoO}_{2}\left(\mathrm{~L}^{\mathrm{H}}\right)(\mathrm{MeOH}], 122-172{ }^{\circ} \mathrm{C}\right.$ for $\left[\mathrm{MoO}_{2}\left(\mathrm{~L}^{3 \mathrm{OMe}}\right)\right.$ $(\mathrm{MeOH})]$, and $74-95^{\circ} \mathrm{C}$ for $\left[\mathrm{MoO}_{2}\left(\mathrm{~L}^{4 \mathrm{OMe}}\right)(\mathrm{MeOH})\right]$ that were related to the loss of coordinated methanol, while the second step in the range $260-580{ }^{\circ} \mathrm{C}, 252-543{ }^{\circ} \mathrm{C}$, and $275-469^{\circ} \mathrm{C}$, respectively corresponded to mass losses issued from the complex decomposition. For oligomeric complexes, the thermal decomposition was in one step only, in the range $238-538^{\circ} \mathrm{C}$ for $\left[\mathrm{MoO}_{2}\left(\mathrm{~L}^{\mathrm{H}}\right)\right]_{\mathrm{n}}, 266-542{ }^{\circ} \mathrm{C}$ for $\left[\mathrm{MoO}_{2}\left(\mathrm{~L}^{3 \mathrm{OMe}}\right)\right]_{\mathrm{n}}, 221-527^{\circ} \mathrm{C}$ for $\left[\mathrm{MoO}_{2}\left(\mathrm{~L}^{4 \mathrm{OMe}}\right)\right]_{\mathrm{n}}$. This decomposition was attributed to the complex breakdown. All residues were analyzed and confirmed to be $\mathrm{MoO}_{3}$.

An interesting observation has been noticed for all the monomeric complexes. Their heating in solid form to the temperature at which coordinated methanol decoordinates, $155{ }^{\circ} \mathrm{C}$ $\left[\mathrm{MoO}_{2}\left(\mathrm{~L}^{\mathrm{H}}\right)(\mathrm{MeOH}], 175^{\circ} \mathrm{C}\right.$ for $\left[\mathrm{MoO}_{2}\left(\mathrm{~L}^{3 \mathrm{OMe}}\right)(\mathrm{MeOH})\right]$, and $100^{\circ} \mathrm{C}$ for $\left[\mathrm{MoO}_{2}\left(\mathrm{~L}^{4 \mathrm{OMe}}\right)(\mathrm{MeOH})\right]$, results with the formation of appropriate oligomeric complex $\left[\mathrm{MoO}_{2}\left(\mathrm{~L}^{\mathrm{H}}\right)\right]_{\mathrm{n}},\left[\mathrm{MoO}_{2}\left(\mathrm{~L}^{3 \mathrm{OMe}}\right)\right]_{\mathrm{n}}$, and $\left[\mathrm{MoO}_{2}\left(\mathrm{~L}^{4 \mathrm{OMe}}\right)\right]_{\mathrm{n}}$. This was a valuable feature since it reveals a new synthetic pathway for oligomeric catalyst preparation, that does not involve $\mathrm{DCM}$ as a solvent, considering $\mathrm{MeOH}$ only, a recommended and environmentally suitable reaction media.

The crystal and molecular structure of two new complexes, $\left[\mathrm{MoO}_{2}\left(\mathrm{~L}^{3 \mathrm{OMe}}\right)(\mathrm{MeOH})\right]$ and $\left[\mathrm{MoO}_{2}\left(\mathrm{~L}^{4 \mathrm{OMe}}\right)(\mathrm{MeOH})\right] \cdot 4,4$-byp, (byp = bypiridine) were determined, whereas crystal structures of the related complexes $\left[\mathrm{MoO}_{2}\left(\mathrm{~L}^{\mathrm{H}}\right)(\mathrm{MeOH})\right][16],\left[\mathrm{MoO}_{2}\left(\mathrm{~L}^{3 \mathrm{OMe}}\right)\left(\mathrm{H}_{2} \mathrm{O}\right)\right]$ [17] and $\left[\mathrm{MoO}_{2}\left(\mathrm{~L}^{4 \mathrm{OMe}}\right)(\mathrm{MeOH})\right] \cdot \mathrm{MeOH}[18]$ were already reported in the literature. The studied complexes exhibit robust coordinative and geometrical features which were preserved throughout the whole class of hydrazonato dioxomolybdenum(VI) species. The cis-dioxomolybdenum $\left\{\mathrm{MoO}_{2}\right\}^{2+}$ core was found to be coordinated by doubly deprotonated ligand in its hydrazidato form if considering hydrazone functional group (Supplementary Materials Table S2). The coordination is achieved through a geometrically convenient ONO coordination pocket built from aryl 2-oxo group, imine nitrogen atom, and hydrazone group oxygen atom (Figure 1a,b). The sixth coordination place of $\left\{\mathrm{MoO}_{2}\right\}^{2+}$ core was coordinated by methanol hydroxy group, even when competing for nitrogen auxiliary is introduced in case of $\left[\mathrm{MoO}_{2}\left(\mathrm{~L}^{4 \mathrm{OMe}}\right)(\mathrm{MeOH})\right] \cdot 4,4-$-bpy. Molecules of complexes were connected via hydrogen bonding into supramolecular dimers (Figure 1c,d), which were furthermore densely packed, forming crystal structures with no solvent-accessible voids found (Supplementary Materials Figures S4 and S5). All aforementioned observations were in line with previously reported structures of similar compounds. However, it was beneficial to compare the geometrical features of complexes and try to connect them with observed performance, to build knowledge for the development of materials with desirable properties (Supplementary Materials Figure S6). If one considers octahedral distortion of 
$\left\{\mathrm{MoO}_{2}\right\}^{2+}$ core and planarity of the coordinated ligand as relevant geometrical parameters, it can be seen (Table 1) that these parameters significantly deviate depending on the ligand substituent and solvent coordinated at the sixth coordination place, even though coordination geometry remains relatively similar (Supplementary Materials Table S1). Indeed, this sample of crystal structures was too small for definitive structure-property correlation, but gives additional motivation for further investigation of this type of complexes.

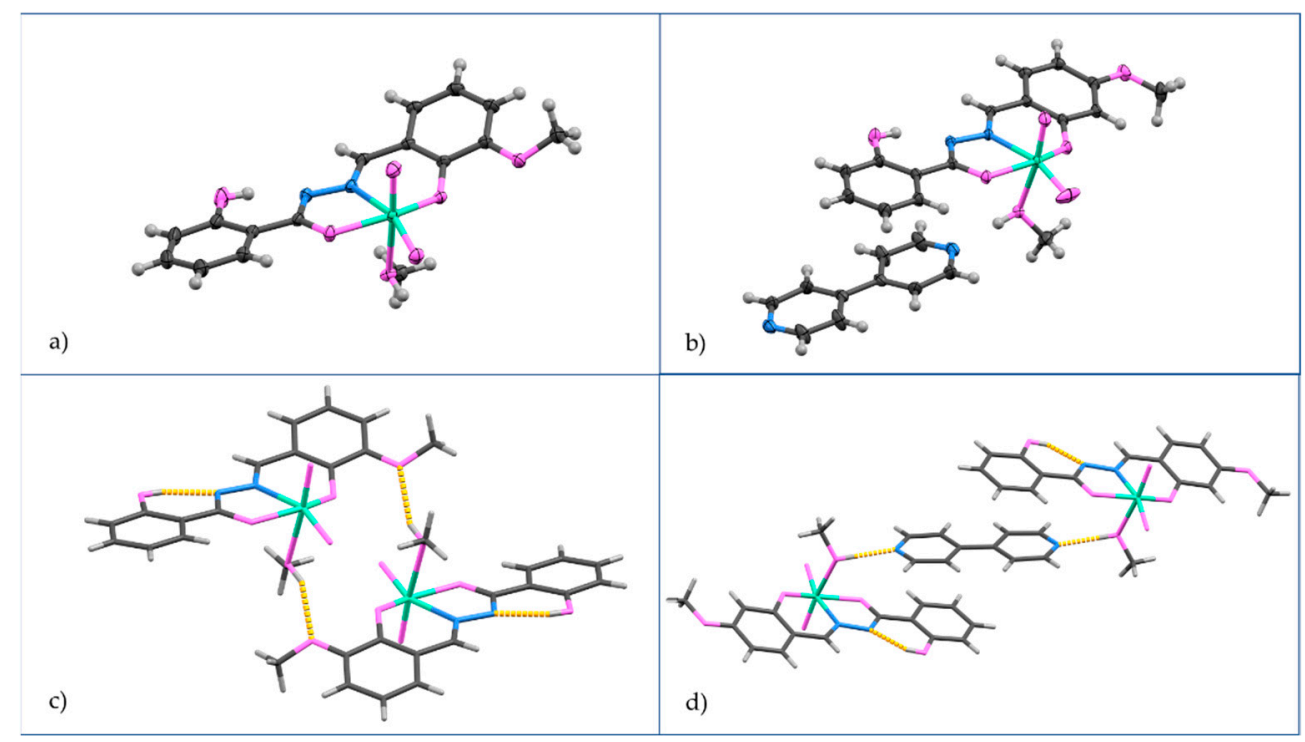

Figure 1. Molecular structure of (a) complex $\left[\mathrm{MoO}_{2}\left(\mathrm{~L}^{3 \mathrm{OMe}}\right)(\mathrm{MeOH})\right]$ and $(\mathbf{b})$ complex co-crystal $\left[\mathrm{MoO}_{2}\left(\mathrm{~L}^{4 \mathrm{OMe}}\right)(\mathrm{MeOH})\right] \cdot 4,4$-bpy. Carbon atoms are colored dark gray, hydrogen atoms light gray, oxygen atoms pink, nitrogen atoms blue, and molybdenum atoms turquoise. Molecules are connected via hydrogen bonds into supramolecular dimers. In the case of $(\mathbf{c})\left[\mathrm{MoO}_{2}\left(\mathrm{~L}^{3 \mathrm{OMe}}\right)(\mathrm{MeOH})\right]$ hydrogen bonds are realized through methanol-methoxy group interaction, while in $(\mathrm{d})\left[\mathrm{MoO}_{2}\left(\mathrm{~L}^{4 \mathrm{OMe}}\right)(\mathrm{MeOH})\right] \cdot 4,4$-bpy they are realized through methanol-bipyridine interaction.

Table 1. Selected geometrical parameters of complexes in the solid-state.

\begin{tabular}{lcc}
\hline \multicolumn{1}{c}{ Compound } & ONO Plane $\times$ Mo Distance/A & Aryl Interplanar Angle $^{\circ}$ \\
\hline$\left[\mathrm{MoO}_{2}\left(\mathrm{~L}^{\mathrm{H}}\right)(\mathrm{MeOH})\right]$ & 0.334 & 6.59 \\
{$\left[\mathrm{MoO}_{2}\left(\mathrm{~L}^{3 \mathrm{OMe}}\right)\left(\mathrm{H}_{2} \mathrm{O}\right)\right]$} & 0.277 & 3.80 \\
{$\left[\mathrm{MoO}_{2}\left(\mathrm{~L}^{3 \mathrm{OMe}}\right)(\mathrm{MeOH})\right]$} & 0.282 & 20.92 \\
{$\left[\mathrm{MoO}_{2}\left(\mathrm{~L}^{4 \mathrm{OMe}}\right)(\mathrm{MeOH})\right] \cdot \mathrm{MeOH}$} & 0.270 & 2.98 \\
{$\left[\mathrm{MoO}_{2}\left(\mathrm{~L}^{4 \mathrm{OMe}}\right)(\mathrm{MeOH})\right] \cdot 4,4-\mathrm{bpy}$} & 0.328 & 9.31 \\
\hline
\end{tabular}

\subsection{Catalytic Results}

All obtained, monomeric and oligomeric complexes, were used as epoxidation catalysts, using cyclooctene as a substrate, and tested oxidants were TBHP in decane or TBHP in water. No other organic solvents were added to the reaction mixture, justifying the green chemistry protocols. Kinetic profiles for all the complexes are presented in Figure 2 and the obtained results are compiled in Table 2. 


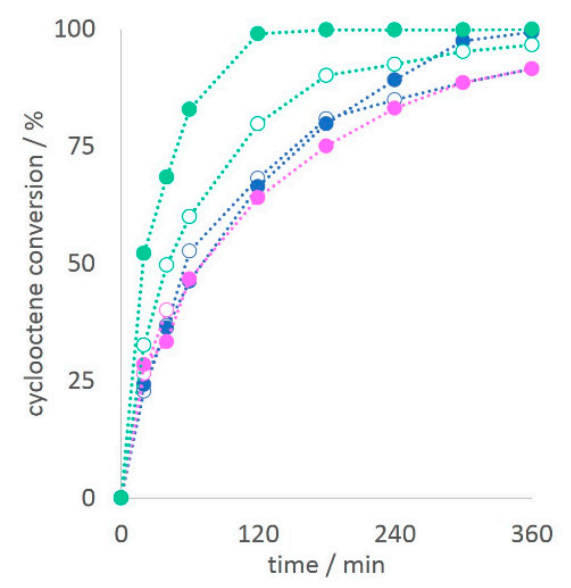

(a)

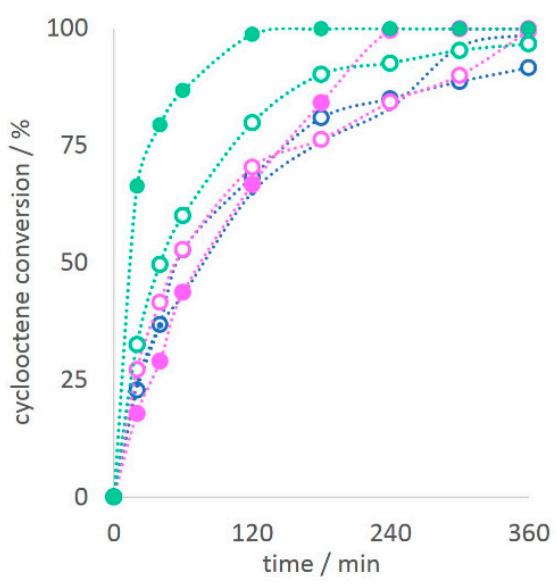

(b)

Figure 2. Kinetic profiles of cyclooctene conversion with (a) oligomeric catalysts and (b) monomeric catalysts. The colored sphere presents the reaction with TBHP in decane and the empty circle presents the reaction with THBP in water. Blue circles are complexes obtained from $\mathrm{H}_{2} \mathrm{~L}^{\mathrm{H}}$ ligand, green complexes obtained from $\mathrm{H}_{2} \mathrm{~L}^{3 \mathrm{OMe}}$ ligand, and pink complexes obtained from $\mathrm{H}_{2} \mathrm{~L}^{4 \mathrm{OMe}}$ ligand.

Table 2. Catalytic results of cis-cyclooctene epoxidation. Reaction conditions: time, $6 \mathrm{~h}$; temperature, $80{ }^{\circ} \mathrm{C}, n$ (catalyst)/ $n$ (cyclooctene) $/ n$ (oxidant $)=0.05 \mathrm{mmol} / 20 \mathrm{mmol} / 40 \mathrm{mmol}$.

\begin{tabular}{|c|c|c|c|c|c|c|c|c|}
\hline \multirow[t]{2}{*}{ Catalyst } & \multicolumn{2}{|c|}{ Conversion ${ }^{a} / \%$} & \multicolumn{2}{|c|}{ Selectivity ${ }^{b} / \%$} & \multicolumn{2}{|c|}{$\mathrm{TOF}_{20 \min }{ }^{\mathrm{c}}$} & \multicolumn{2}{|c|}{ TON $^{d}$} \\
\hline & ТВНPaq & TBHPdec & TBHPaq & TBHPdec & TBHPaq & TBHPdec & TBHPaq & TBHPdec \\
\hline$\left[\mathrm{MoO}_{2}\left(\mathrm{~L}^{\mathrm{H}}\right)\right]_{\mathrm{n}}$ & 90 & 99 & 88 & 91 & 290 & 290 & 361 & 397 \\
\hline$\left[\mathrm{MoO}_{2}\left(\mathrm{~L}^{\mathrm{H}}\right)(\mathrm{MeOH})\right]$ & 92 & 98 & 90 & 90 & 274 & 290 & 368 & 397 \\
\hline$\left[\mathrm{MoO}_{2}\left(\mathrm{~L}^{3 \mathrm{OMe}}\right)\right]_{\mathrm{n}}$ & 96 & 99 & 93 & 90 & 391 & 625 & 386 & 399 \\
\hline$\left[\mathrm{MoO}_{2}\left(\mathrm{~L}^{3 \mathrm{OMe}}\right)[\mathrm{MeOH})\right]$ & 96 & 99 & 95 & 93 & 496 & 796 & 400 & 400 \\
\hline$\left[\mathrm{MoO}_{2}\left(\mathrm{~L}^{4 \mathrm{OMe}}\right)\right]_{\mathrm{n}}$ & 94 & 99 & 92 & 93 & 319 & 298 & 373 & 399 \\
\hline$\left[\mathrm{MoO}_{2}\left(\mathrm{~L}^{4 \mathrm{OMe}}\right)(\mathrm{MeOH})\right]$ & 99 & 99 & 85 & 92 & 326 & 214 & 351 & 400 \\
\hline
\end{tabular}

As previously observed with other pentacoordinate $\left[\mathrm{MoO}_{2} \mathrm{~L}\right]$ complexes bearing ligands with very close geometries than those studied here, TBHP in decane provided better results in terms of conversion and selectivity than TBHP in water. However, for all the complexes used, the cyclooctene conversion after $6 \mathrm{~h}$ was almost complete, and selectivity towards the epoxide being higher than $90 \%$. At the difference with previously published results, it was surprising to observe that the process using TBHP in water as an oxidant gave herein excellent results with the studied complexes. Indeed, all complexes showed conversion of cyclooctene in the range $90-99 \%$, the monomeric complex $\left[\mathrm{MoO}_{2}\left(\mathrm{~L}^{4 \mathrm{OMe}}\right)(\mathrm{MeOH})\right]$ giving the highest conversion and the oligomeric complex $\left[\mathrm{MoO}_{2}\left(\mathrm{~L}^{\mathrm{H}}\right)\right]_{\mathrm{n}}$ the lowest one. Selectivity towards cyclooctene oxide is within the range $85-95 \%$, being the lowest for $\left[\mathrm{MoO}_{2}\left(\mathrm{~L}^{4 \mathrm{OMe}}\right)(\mathrm{MeOH})\right]$ and $\left[\mathrm{MoO}_{2}\left(\mathrm{~L}^{\mathrm{H}}\right)\right]_{\mathrm{n}}$, and the highest for $\left[\mathrm{MoO}_{2}\left(\mathrm{~L}^{3 \mathrm{OMe}}\right)(\mathrm{MeOH})\right]$. The greatest difference could be noticed with the $\mathrm{TOF}_{20 \mathrm{~min}}$ values relative to the oxidant carrier (water vs. decane). Highest TOFs observed for $\left[\mathrm{MoO}_{2}\left(\mathrm{~L}^{3 \mathrm{OMe}}\right)(\mathrm{MeOH})\right]$ and $\left[\mathrm{MoO}_{2}\left(\mathrm{~L}^{3 \mathrm{OMe}}\right)\right]_{\mathrm{n}}$ show that the catalytic activity is ligand-dependent. Another factor to discuss comes from the complete proposed postulated mechanism, where the active species was a pentacoordinate species $\left[\mathrm{MoO}_{2} \mathrm{~L}\right]$ and its formation had to be reached from the complexes added into the reaction media. According to it, $\left[\mathrm{MoO}_{2}\left(\mathrm{~L}^{3 \mathrm{OMe}}\right)(\mathrm{MeOH})\right]$ and $\left[\mathrm{MoO}_{2}\left(\mathrm{~L}^{3 \mathrm{OMe}}\right)\right]_{\mathrm{n}}$ might have the same active species, i.e., $\left[\mathrm{MoO}_{2}\left(\mathrm{~L}^{3 \mathrm{OMe}}\right)\right]$. Thus, to compare the activity from both complexes, cyclooctene conversion and epoxide production 
were followed in the first hour of the reaction and are presented in Figure 3. As seen, even if induction periods can be noticed for both catalysts in the first $20 \mathrm{~min}$ of the reaction, the monomeric catalyst $\left[\mathrm{MoO}_{2}\left(\mathrm{~L}^{3 \mathrm{OMe}}\right)(\mathrm{MeOH})\right]$ became more active in a shorter time. In relationship with the postulated mechanism, experimental data confirmed that the energy needed to decoordinate the solvent seems lower than for the oligomeric compound. This was observed already with similar species.

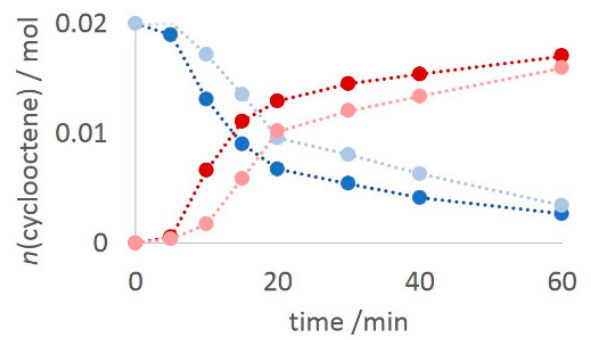

Figure 3. Cyclooctene conversion (falling curves) and corresponding epoxide formation (rising curve) for the first $60 \mathrm{~min}$ of the reaction. Dark red and dark blue curves present the reaction with the catalyst $\left[\mathrm{MoO}_{2}\left(\mathrm{~L}^{3 \mathrm{OMe}}\right)(\mathrm{MeOH})\right]$, while pale red and pale blue curves present the reaction with the catalyst $\left[\mathrm{MoO}_{2}\left(\mathrm{~L}^{3 \mathrm{OMe}}\right)\right]_{\mathrm{n}}$.

The reported research with the monomeric complexes $\left[\mathrm{MoO}_{2}(\mathrm{~L})(\mathrm{EtOH})\right]$, where $\mathrm{L}$ represents the coordinated ligand obtained from 4-hydroxybenzhydrazide, showed great activity of the catalyst, but moderate selectivity towards epoxide, when using TBHP in water [11]. This implied a positive effect of the 2-hydroxybenzhydrazide, applied in this research, and easier formation of the pentacoordinate active species, $\left[\mathrm{MoO}_{2}(\mathrm{~L})\right]$, that participated in the catalytic cycle. $\mathrm{TOF}_{20 \mathrm{~min}}$ values for the reported complexes varied between 350 and 469, while TON parameter was in the range 354 and 368, similar to the results reported herein. Furthermore, similar investigations employing polymeric catalysts, $\left[\mathrm{MoO}_{2}(\mathrm{~L})\right]_{n}$, obtained from the ligands containing nicotinic acid hydrazide moiety, showed much lower activity and selectivity towards epoxide with TBHP in water, while by applying TBHP in decane the catalytic results improved drastically.

\subsection{Theoretical Considerations}

The experimental results show that the 3-methoxy group on the ligand seems to enhance considerably the activity of the molybdenum complexes, with the best TOFs observed among the three ligands studied (for monomeric and oligomeric complexes). In addition, decane was proved earlier to be a superior TBHP carrier than water and to favor the reactivity of the Mo complexes. The presence of water (from aqueous TBHP) can potentially inhibit the catalytic system, but the observed conversion difference was minimal in the present investigation. Since activity was quite high and conversion important, such behavior was visible here only within the TOF where the discrepancy of values between ligands was higher for TBHP in water than for TBHP in decane. As a reminder, the postulated mechanism and a corresponding DFT study gave interesting insight. Previously, several Mo complexes have been examined through a systematic DFT study. As an example, on the $\left[\mathrm{MoO}_{2}(\mathrm{SAP})\right]$ complexes and different substitutions on ligand showed that the presence of $\mathrm{OH}$ group (on a specific position on the aldehyde part) [19] or $\mathrm{NO}_{2}$ substituent (on aminophenol part) [20] on the ligand provoked higher activity. The presence of 3- and 4-methoxy groups on the ligand was studied several times with other Mo complexes [21]. The trend observed experimentally among similar complexes could be confirmed theoretically in all the cases, but it was not possible to establish a general rule linking the activity of the complexes and the methoxy position/presence. Thus, it was interesting to study the presented complexes based on the previous works to see the relationship between experiment and theory among the three pentacoordinate species. Since those complexes were very efficient under the same conditions applied as in previous studies, the research interest was to correlate the activity and thermodynamic values, for ex- 
ample, the TS values. To be consistent, calculations were limited to the part responsible for the oxygen transfer, i.e., starting from the monomeric species $\left[\mathrm{MoO}_{2}(\mathrm{~L})(\mathrm{MeOH})\right]$. Thus, the different studied steps include the complex desolvation to reach the pentacoordinate species (step 0), the formation of the $\left[\mathrm{MoO}_{2}(\mathrm{~L})(\mathrm{TBHP})\right]$ adduct (step I), and the approach of the olefin to the $\mathrm{O}_{\beta}$ (step II) that was implicated in the epoxide formation. The calculations were limited to the conditions in the gas phase since it was demonstrated earlier that trends obtained through PCM corrections and gas-phase were similar. Those data are gathered in Table 3. The adducts and the TS were indicated in Scheme 3. All optimized geometries are collected in Supplementary Materials Tables S4-S6.

Table 3. Enthalpy values $(\Delta \mathrm{H})\left(\right.$ in $\mathrm{kcal} \mathrm{mol}^{-1}$ ) for each step depicted in Scheme 3 .

\begin{tabular}{|c|c|c|c|c|c|c|c|}
\hline & \multirow[b]{2}{*}{ Steps } & \multicolumn{3}{|c|}{ Absolute Values } & \multicolumn{3}{|c|}{ Relative to $\mathrm{MoO}_{2}(\mathrm{~L})(\mathrm{MeOH})$} \\
\hline & & $\mathrm{MoO}_{2}\left(\mathrm{~L}^{\mathrm{H}}\right)$ & $\mathrm{MoO}_{2}\left(\mathrm{~L}^{3 \mathrm{OMe}}\right)$ & $\mathrm{MoO}_{2}\left(\mathrm{~L}^{4 O m e}\right)$ & $\mathrm{MoO}_{2}\left(\mathrm{~L}^{\mathrm{H}}\right)$ & $\mathrm{MoO}_{2}\left(\mathrm{~L}^{3 \mathrm{OMe}}\right)$ & $\mathrm{MoO}_{2}\left(\mathrm{~L}^{4 \mathrm{OMe}}\right)$ \\
\hline$(0)$ & $\mathrm{MeOH}$ decoordination & +9.7 & +9.5 & +9.4 & +9.7 & +9.5 & +9.4 \\
\hline (I) & TBHP coordination & -8.7 & -8.9 & -8.4 & +1.0 & +0.6 & +0.9 \\
\hline (II) & TS barrier & +23.0 & +23.2 & +23.5 & +24.0 & +23.8 & +24.4 \\
\hline (III) & Release of epoxide & -51.4 & -51.7 & -51.7 & -27.3 & -27.9 & -27.3 \\
\hline (IV) & Regeneration of catalyst & -4.3 & -4.1 & -4.7 & -31.7 & -31.9 & -32.0 \\
\hline
\end{tabular}

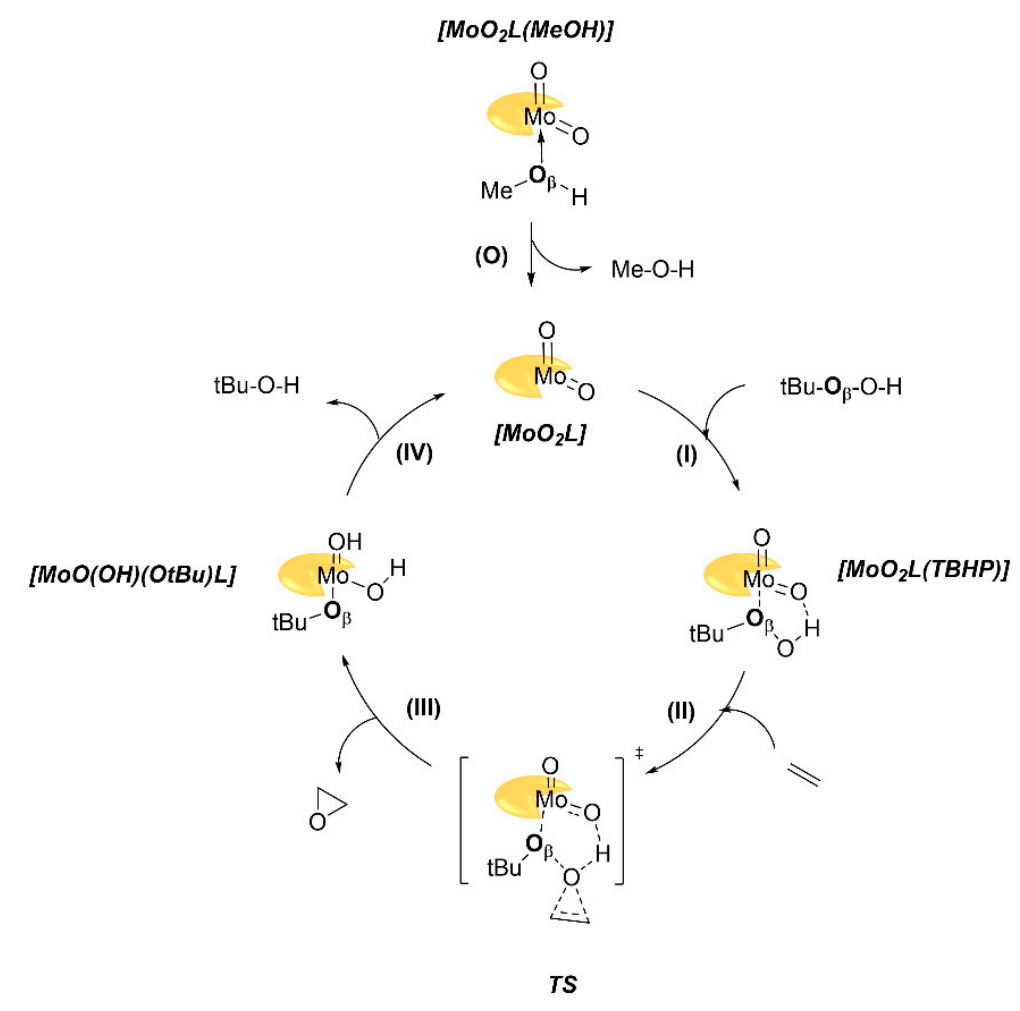

Scheme 3. Presentation of the postulated mechanism for the epoxidation olefin. The colored shape symbolizes the ligand. The $\mathrm{O}_{\beta}$ is indicated in bold in each structure. The calculated structures have been indicated in bold. The different steps are indicated with numbers close to the arrows.

From the absolute values obtained by calculations for each step, the decoordination of the methanol (step 0$)$ is more favored with $\left[\mathrm{MoO}_{2}\left(\mathrm{~L}^{4 \mathrm{OMe}}\right)(\mathrm{MeOH})\right]$ complex, which can be as well seen experimentally through TG analysis. The stabilization of the pentacoordinate species $\left[\mathrm{MoO}_{2}(\mathrm{~L})\right]$ with TBHP (step I) was stronger in the case of $\left[\mathrm{MoO}_{2}\left(\mathrm{~L}^{3 \mathrm{OMe}}\right)\right](8.9 \mathrm{kcal}$ $\mathrm{mol}^{-1}$ ). The TS energy (step II) was smaller for $\left[\mathrm{MoO}_{2}\left(\mathrm{~L}^{\mathrm{H}}\right)\right]$ with $23.0 \mathrm{kcal} \mathrm{mol}{ }^{-1}$, i.e., around $0.2-0.5 \mathrm{kcal} \mathrm{mol}^{-1}$ more favorable than the two other complexes. Steps III and IV were not important for the discussion but are indicated in the table. The experimental TOF values showed that complexes bearing $\left[\mathrm{MoO}_{2}\left(\mathrm{~L}^{3 \mathrm{OMe}}\right)\right]$ are the fastest. This observation 
could be done if the energy necessary to form the pentacoordinate species (step 0) is added, i.e., the energy needed for the methanol decoordination. Thus, the TS value was the lowest (in relative value) for $\left[\mathrm{MoO}_{2}\left(\mathrm{~L}^{3 \mathrm{OMe}}\right)\right]$. The difference is very low, and it has to be seen that the important discussion is about the TOF and not the better activity since it has been shown that there is not a high difference of activity between the three ligands. Those data can be linked to the geometrical data.

The Table 4 gathered relevant distances and one dihedral angle (related to ligand planarity) around the molybdenum atom, with numbering according to Scheme 4 . Experimental results showed that the $\left[\mathrm{MoO}_{2}\left(\mathrm{~L}^{3 \mathrm{OMe}}\right)\right]$ species seemed to be the best catalyst. Some geometrical parameters were discussed. Thus, as seen in energy diagram, Mo- $\mathrm{O}_{\beta}$ interatomic distance parameter influenced the TS path mainly (step II). The shorter this distance, the smaller the TS. This factor favored the path with $\left[\mathrm{MoO}_{2}\left(\mathrm{~L}^{\mathrm{H}}\right)\right]$. This was certainly linked to electronic and steric effects. Interesting facts appeared with the two nitrogen atoms, i.e., $\mathrm{N}^{1}$ (linked to $\mathrm{Mo}$ ) and $\mathrm{N}^{2}$ (linked to the hydrogen of the pending $\mathrm{OH}$ moiety). In all the steps, although if a slight difference was observed, the $\mathrm{N}^{2} \cdots \mathrm{H}$ bond was shorter for $\left[\mathrm{MoO}_{2}\left(\mathrm{~L}^{3 \mathrm{OMe}}\right)\right]$ catalyst. At the difference, the impact on the $\mathrm{N}^{1} \cdots$ Mo interatomic distance was more visible with the longest distance with the same catalyst. This seems to give an additional clue of the electronic effect and subsequently to the mechanism, showing that a stronger Mo stabilization through $\mathrm{N}^{1}$ atom does not favor the reactivity, and this stabilization is influenced by the $\mathrm{N}^{2} \cdots \mathrm{H}$ stabilization. Of note, the $\mathrm{MoO}_{2}$ fragment was mostly identical with the three ligands.

Table 4. Interatomic distances $(\AA)$ and dihedral angle $\left(^{\circ}\right)$ for the calculated structures according to Scheme 4.

\begin{tabular}{|c|c|c|c|c|c|}
\hline & & {$\left[\mathrm{MoO}_{2} \mathrm{~L}(\mathrm{MeOH})\right]$} & {$\left[\mathrm{MoO}_{2}(\mathrm{~L})\right]$} & {$\left[\mathrm{MoO}_{2}(\mathrm{~L})(\mathrm{TBHP})\right]$} & TS \\
\hline & \multicolumn{5}{|c|}{ Interatomic distances } \\
\hline \multirow{3}{*}[\mathrm{Mo}-\mathrm{O}_{\beta}]{} & $\mathrm{L}^{\mathrm{H}}$ & 2.498 & - & 2.970 & 2.385 \\
\hline & $\mathrm{L}^{3 \mathrm{OMe}}$ & 2.498 & - & 2.975 & 2.388 \\
\hline & $\mathrm{L}^{4 \mathrm{OMe}}$ & 2.507 & - & 3.000 & 2.398 \\
\hline \multirow{3}{*}{$\mathrm{N}^{2} \cdots \mathrm{H}$} & $\mathrm{L}^{\mathrm{H}}$ & 1.763 & 1.781 & 1.776 & 1.755 \\
\hline & $\mathrm{L}^{3 \mathrm{OMe}}$ & 1.761 & 1.779 & 1.775 & 1.753 \\
\hline & $\mathrm{L}^{4 \mathrm{OMe}}$ & 1.764 & 1.781 & 1.777 & 1.756 \\
\hline \multirow{3}{*}{$\mathrm{N}^{1}-\mathrm{Mo}$} & $\mathrm{L}^{\mathrm{H}}$ & 2.295 & 2.272 & 2.268 & 2.278 \\
\hline & $\mathrm{L}^{3 \mathrm{OMe}}$ & 2.297 & 2.275 & 2.271 & 2.281 \\
\hline & $\mathrm{L}^{4 \mathrm{OMe}}$ & 2.283 & 2.255 & 2.255 & 2.266 \\
\hline \multirow{3}{*}{$\mathrm{Mo}=-\mathrm{O}^{1}( \pm$ plane $)$} & $\mathrm{L}^{\mathrm{H}}$ & 1.702 & 1.694 & 1.714 & 1.732 \\
\hline & $\mathrm{L}^{3 \mathrm{OMe}}$ & 1.702 & 1.696 & 1.714 & 1.733 \\
\hline & $\mathrm{L}^{4 \mathrm{OMe}}$ & 1.703 & 1.697 & 1.715 & 1.733 \\
\hline \multirow{4}{*}{ Mo-O ${ }^{2}(\perp$ plane $)$} & $\mathrm{L}^{\mathrm{H}}$ & 1.694 & 1.695 & 1.690 & 1.692 \\
\hline & $\mathrm{L}^{3 \mathrm{OMe}}$ & 1.695 & 1.695 & 1.691 & 1.693 \\
\hline & $\mathrm{L}^{4 \mathrm{OMe}}$ & 1.695 & 1.695 & 1.691 & 1.692 \\
\hline & \multicolumn{5}{|c|}{ Interatomic angle } \\
\hline \multirow{3}{*}{ OCNO dihedral angle } & $\mathrm{L}^{\mathrm{H}}$ & -9.26 & -6.03 & -11.56 & -16.78 \\
\hline & $\mathrm{L}^{3 \mathrm{OMe}}$ & -9.58 & -6.36 & -11.01 & -16.19 \\
\hline & $\mathrm{L}^{4 \mathrm{OMe}}$ & -9.15 & -5.73 & -11.34 & -16.70 \\
\hline
\end{tabular}




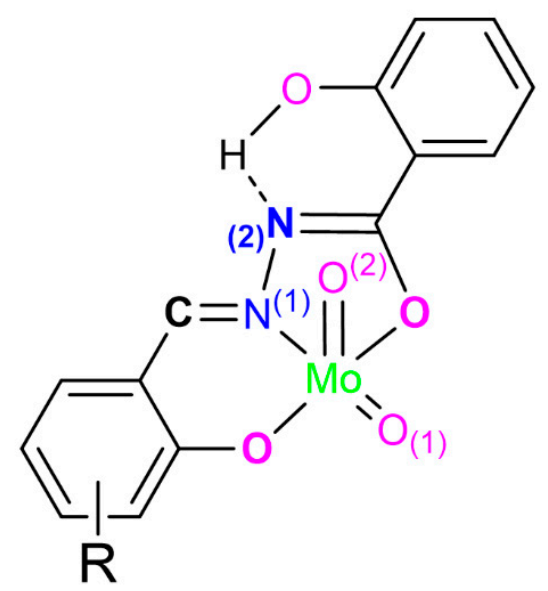

Scheme 4. Representation of the $\mathrm{MoO}_{2} \mathrm{~L}$ complex with the numbering of the atoms taken into consideration. For the dihedral angle, follow OCNO (bold letters) in clockwise order.

The ligand distortion seemed to have an influence. While $\left[\mathrm{MoO}_{2}\left(\mathrm{~L}^{3 \mathrm{OMe}}\right)(\mathrm{MeOH})\right]$ has the highest dihedral angle, showing the lowest planarity, $\left[\mathrm{MoO}_{2}\left(\mathrm{~L}^{3 \mathrm{OMe}}\right)(\mathrm{TBHP})\right]$ and its corresponding TS exhibited the most planar geometry. Thus, in accordance with the thermodynamic calculations, additional information on the mechanism with ligand planarity was interesting. Stronger ligand distortion in the case of $\left[\mathrm{MoO}_{2}(\mathrm{~L})\right]$ and related methanol adduct implied a lower ligand distortion when coordinated with THBP and within the TS. Those two factors were encountered for the process using $\left[\mathrm{MoO}_{2}\left(\mathrm{~L}^{3 \mathrm{OMe}}\right)\right]$ catalyst.

\section{Materials and Methods}

Preparative part. The starting compounds used, aldehydes and hydrazide (Aldrich), as well as the solvents, $\mathrm{DCM}$ and $\mathrm{MeOH}$ (Fluka), were commercially available, without any purification. The starting complexes $\left[\mathrm{MoO}_{2}(\mathrm{acac})_{2}\right]\left(\mathrm{acac}=\mathrm{C}_{5} \mathrm{H}_{7} \mathrm{O}_{2}=\right.$ acetylacetonate $)$ was prepared as described in the literature $[22,23]$.

\subsection{Synthesis of Ligands}

Ligand preparation by solution-based synthesis: Ligands $\mathrm{H}_{2} \mathrm{~L}^{\mathrm{H}}, \mathrm{H}_{2} \mathrm{~L}^{3 \mathrm{OMe}}, \mathrm{H}_{2} \mathrm{~L}^{4 \mathrm{OMe}}$ and were prepared by condensation of aldehyde and hydrazide, according to the reported procedure [24-26]. Ligand preparation by mechanochemical synthesis: Liquid assisted grinding (LAG) experiments were performed using a Retsch MM200 ball mill. $0.1044 \mathrm{~g}(0.7 \mathrm{mmol})$ of benzaldehyde, 3- or 4-methoxysalicylaldehyde, $0.1041 \mathrm{~g}(0.7 \mathrm{mmol})$ 2-hydroxy-benzydrazide, and $50 \mu \mathrm{L}$ of methanol were placed with one $10 \mathrm{~mm}$ milling ball in a $10 \mathrm{~mL}$ Teflon jar. For the preparation of $\mathrm{H}_{2} \mathrm{~L}^{\mathrm{H}}$ no solvent was added to the mixture of salicylaldehyde, $0.085 \mathrm{~g}(0.7 \mathrm{mmol})$ and hydrazide $(0.7 \mathrm{mmol})$. A sample of the powder obtained by milling at $25 \mathrm{~Hz}$, after $45 \mathrm{~min}$, was immediately analyzed by PXRD and compared to the compound obtained by solution-based synthesis. No purification of the sample was performed.

$\mathrm{H}_{2} \mathrm{~L}^{\mathrm{H}}$ : DSC onset: $284{ }^{\circ} \mathrm{C}$. The endothermic peak corresponding to the melting process: $51.2 \mathrm{~kJ} / \mathrm{mol} . \mathrm{H}_{2} \mathrm{~L}^{3 \mathrm{OMe}}$ : DSC onset: $250^{\circ} \mathrm{C}$. The endothermic peak corresponding to the melting process: $48.7 \mathrm{~kJ} / \mathrm{mol} . \mathrm{H}_{2} \mathrm{~L}^{4 \mathrm{OMe}}$ : DSC onset: $256^{\circ} \mathrm{C}$. The endothermic peak corresponding to the melting process: $49.0 \mathrm{~kJ} / \mathrm{mol}$.

\subsection{Synthesis of Molybdenum(VI) Complexes}

A mixture of $\left[\mathrm{MoO}_{2}(\mathrm{acac})_{2}\right](0.64 \mathrm{~g}, 2 \mathrm{mmol})$ and $\mathrm{H}_{2} \mathrm{~L}^{\mathrm{H}}, 3 \mathrm{OMe}$ or $4 \mathrm{OMe}(2 \mathrm{mmol})$ in methanol $(120 \mathrm{~mL})$ or DCM $(140 \mathrm{~mL})$ was refluxed for four hours. The solution was left at room temperature and the resulting crystalline substance was filtered and dried in a desiccator up to a constant weight. 


\subsubsection{Oligomeric Complexes (Obtained from DCM)}

$\left[\mathrm{MoO}_{2}\left(\mathrm{~L}^{\mathrm{H}}\right)\right]_{\mathrm{n}}$. Red product. Yield: $0.61 \mathrm{~g}, 82 \%$. Calc. for $\mathrm{C}_{14} \mathrm{H}_{10} \mathrm{MoN}_{2} \mathrm{O}_{5}$ (382.18): C, 44.0; $\mathrm{H}, 2.6 ; \mathrm{N}, 7.3$. Found: $\mathrm{C}, 44.3 ; \mathrm{H}, 2.9 ; \mathrm{N}, 7.0 \%$. TG: calc. for $\mathrm{MoO}_{3} 37.6 \%$, found $36.2 \%$. Selected IR data $\left(\mathrm{cm}^{-1}\right): 1618(\mathrm{C}=\mathrm{N}), 1378$ (C-Ophenolate), 1341 (C-Oenolate), 950, 910 $\left(\mathrm{MoO}_{2}\right), 850(\mathrm{O}=\mathrm{Mo} \cdots \mathrm{O})$.

$\left[\mathrm{MoO}_{2}\left(\mathrm{~L}^{3 \mathrm{OMe}}\right)\right]_{\mathrm{n}}$. Red brown product. Yield: $0.56 \mathrm{~g}, 78 \%$. Calc. for $\mathrm{C}_{15} \mathrm{H}_{12} \mathrm{MoN}_{2} \mathrm{O}_{6}$ (412.21): C, 43.7; H, 2.9; N, 6.8 Found: $\mathrm{C}, 43.1 ; \mathrm{H}, 2.5 ; \mathrm{N}, 6.1 \%$. TG: calc. for $\mathrm{MoO}_{3}$ $34.9 \%$, found $33.8 \%$. Selected IR data $\left(\mathrm{cm}^{-1}\right): 1624(\mathrm{C}=\mathrm{N}), 1386$ (C-Ophenolate), 1345 (C-Oenolate), 945, $873\left(\mathrm{MoO}_{2}\right), 811(\mathrm{O}=\mathrm{Mo} \cdots \mathrm{O})$.

$\left[\mathrm{MoO}_{2}\left(\mathrm{~L}^{4 \mathrm{OMe}}\right)\right]_{\mathrm{n}}$. Red brown product. Yield: $0.61 \mathrm{~g}, 85 \%$. Calc. for $\mathrm{C}_{15} \mathrm{H}_{12} \mathrm{MoN}_{2} \mathrm{O}_{6}$ (412.21): C, 43.7; H, 2.9; N, 6.8 Found: $\mathrm{C}, 44.3 ; \mathrm{H}, 3.0 ; \mathrm{N}, 6.2 \%$. TG: calc. for for $\mathrm{MoO}_{3}$ $34.9 \%$, found $34.3 \%$. Selected IR data $\left(\mathrm{cm}^{-1}\right): 1623(\mathrm{C}=\mathrm{N}), 1361$ (C-Ophenolate), 1340 (C-Oenolate), 943, $849\left(\mathrm{MoO}_{2}\right), 806(\mathrm{O}=\mathrm{Mo} \cdots \mathrm{O})$.

\subsubsection{Monomeric Complexes (Obtained from $\mathrm{MeOH}$ )}

$\left[\mathrm{MoO}_{2}\left(\mathrm{~L}^{\mathrm{H}}\right)(\mathrm{MeOH})\right]$. Orange red product. Yield: $0.40 \mathrm{~g}, 50 \%$. Calc. for $\mathrm{C}_{15} \mathrm{H}_{14} \mathrm{MoN}_{2} \mathrm{O}_{6}$ (412.21): C, 43.7; $\mathrm{H}, 2.9 ; \mathrm{N}, 6.8$ Found: $\mathrm{C}, 43.1 ; \mathrm{H}, 2.5 ; \mathrm{N}, 6.1 \%$. TG: calc. for $\mathrm{MoO}_{3} 34.9 \%$, found $33.8 \%$. Selected IR data $\left(\mathrm{cm}^{-1}\right): 1618(\mathrm{C}=\mathrm{N}), 1385$ (C-Ophenolate), 1348 (C-Oenolate), $1011(\mathrm{C}-\mathrm{OMeOH}), 939,915\left(\mathrm{MoO}_{2}\right), 903\left(\mathrm{O}=\mathrm{Mo}-\mathrm{O}_{\mathrm{MeOH}}\right)$.

$\left[\mathrm{MoO}_{2}\left(\mathrm{~L}^{3 \mathrm{OMe}}\right)(\mathrm{MeOH})\right]$. Orange product. Yield: $0.50 \mathrm{~g}$, $64 \%$. Calc. for $\mathrm{C}_{16} \mathrm{H}_{16} \mathrm{MoN}_{2} \mathrm{O}_{7}$ (444.25): $\mathrm{C}, 43.3 ; \mathrm{H}, 3.6 ; \mathrm{N}, 6.3$. Found: $\mathrm{C}, 44.0 ; \mathrm{H}, 3.9 ; \mathrm{N}, 5.9 \%$. TG: calc. for $\mathrm{MeOH} 7.2 \%$, found $7.4 \%$, calc. for $\mathrm{MoO}_{3} 32.4 \%$, found $32.2 \%$. Selected IR data $\left(\mathrm{cm}^{-1}\right): 1624(\mathrm{C}=\mathrm{N})$, 1386 (C-Ophenolate), 1345 (C-Oenolate), $1005\left(\mathrm{C}-\mathrm{O}_{\mathrm{MeOH}}\right), 939,920\left(\mathrm{MoO}_{2}\right), 906(\mathrm{O}=\mathrm{Mo}-$ $\mathrm{O}_{\mathrm{MeOH}}$.

$\left[\mathrm{MoO}_{2}\left(\mathrm{~L}^{4 \mathrm{OMe}}\right)(\mathrm{MeOH})\right]$. Orange-red product. Yield: $0.50 \mathrm{~g}, 64 \%$. Calc. for $\mathrm{C}_{16} \mathrm{H}_{16} \mathrm{MoN}_{2} \mathrm{O}_{7}$ (444.25): $\mathrm{C}, 43.3 ; \mathrm{H}, 3.6 ; \mathrm{N}, 6.3$. Found: $\mathrm{C}, 44.0 ; \mathrm{H}, 3.9 ; \mathrm{N}, 5.9 \%$. TG: calc. for $\mathrm{MeOH} 7.2 \%$, found $6.8 \%$, calc. for $\mathrm{MoO}_{3} 32.4 \%$, found $31.5 \%$. Selected IR data $\left(\mathrm{cm}^{-1}\right): 1623(\mathrm{C}=\mathrm{N}), 1378$ (C-Ophenolate), 1345 (C-Oenolate), 942, $927\left(\mathrm{MoO}_{2}\right), 894\left(\mathrm{O}=\mathrm{Mo}-\mathrm{O}_{\mathrm{MeOH}}\right)$.

\subsection{General Procedure for the Epoxidation Of Cyclooctene by TBHP}

A mixture of cyclooctene $(2.76 \mathrm{~mL}, 20 \mathrm{mmol})$, acetophenone as an internal standard, and molybdenum catalyst $(0.05 \mathrm{mmol})$ was stirred and heated to $80^{\circ} \mathrm{C}$ before the addition of TBHP in water $(70 \% w / w, 40 \mathrm{mmol})$ or in decane $(5.5 \mathrm{M}, 40 \mathrm{mmol})$. The reaction was monitored for $6 \mathrm{~h}$ with withdrawal and analysis of organic phase aliquots $(0.1 \mathrm{~mL})$ at required times. Each withdrawn sample was mixed with $1 \mathrm{~mL}$ of $\mathrm{Et}_{2} \mathrm{O}$ and analyzed by GC.

\subsection{Theoretical Calculations}

The geometries of all species under investigation were optimized without any symmetry constraint with the Gaussian 09 rev. D01 program suite [27], with the DFT approach using the B3LYP three-parameter functional [28-30] in conjunction with the 6-31 $\mathrm{G}^{*}$ basis set [31-34] for the light atoms $(\mathrm{O}, \mathrm{N}, \mathrm{C}, \mathrm{H})$ and the CEP-31G set for the Mo atom [35,36]. The geometries of all complexes and intermediates were optimized from starting geometries determined or inspired by X-ray diffraction without any symmetry constraint. All coordinates have been listed in Supplementary Materials. Frequency analysis confirmed that the optimized geometries of all the stable compounds and intermediates were local minima. The transition states were optimized using a preliminary scan of a relevant internal coordinate, followed by full optimization of the TS guided by the knowledge of such coordinates. All optimized geometries were confirmed to be stationary points and local minima (for stable molecules or reaction intermediates) or first order saddle points (for the TSs) by frequency analyses. For all the TSs, analysis of the imaginary frequency confirmed the expected motion along the reaction coordinate. Those values and the relative schemes have been added in Supplementary Materials (Table S4-S6)) The calculated frequencies 
were also used to derive the thermochemical parameters at $298 \mathrm{~K}$ according to the standard approximations (ideal gas, rigid rotor, and harmonic oscillator)

\subsection{Physical Methods}

Elemental analyses were provided by the Analytical Services Laboratory of the Ruđer Bošković Institute, Zagreb. Thermogravimetric (TG) analysis was performed using a Mettler TG 50 thermobalance in aluminum crucibles. All experiments were performed in oxygen atmosphere with a flow rate of $200 \mathrm{~cm}^{3} \mathrm{~min}^{-1}$, with heating rates of $10 \mathrm{~K} \mathrm{~min}^{-1}$. Differential scanning calorimetry (DSC) measurements were carried out using a MettlerToledo DSC823e calorimeter and analyzed by Mettler STARe 9.01. software. IR-ATR spectra were recorded on a Perkin Elmer Spectrum One spectrometer, in the spectral range between $4500-450 \mathrm{~cm}^{-1}$. The catalytic reactions were followed by gas chromatography on an Agilent 6890A chromatograph equipped with an FID detector and a DB5-MS capillary column $(30 \mathrm{~mm} \times 0.32 \mathrm{~mm} \times 0.25 \mathrm{~mm})$. The GC parameters were quantified using authentic samples of the reactants and products. The conversion of cis-cyclooctene and the formation of cyclooctene oxide were calculated from calibration curves $\left(\mathrm{r}^{2}=0.999\right)$ relative to acetophenone as an internal standard.

High quality single crystals of $\left[\mathrm{MoO}_{2}\left(\mathrm{~L}^{3 \mathrm{OMe}}\right)(\mathrm{MeOH})\right]$ and $\left[\mathrm{MoO}_{2}\left(\mathrm{~L}^{4 \mathrm{OMe}}\right)(\mathrm{MeOH})\right] \cdot 4,4-$ bpy were grown from their respective reaction mixtures. 4,4-bpy added to the methanol solution seemed to improve the crystallization. Diffracted intensities were collected on (for $\left.\left[\mathrm{MoO}_{2}\left(\mathrm{~L}^{3 \mathrm{OMe}}\right)(\mathrm{MeOH})\right]\right)$ Rigaku Xcalibur diffractometer equipped with molybdenum source and Sapphire3 detector and (for $\left.\left[\mathrm{MoO}_{2}\left(\mathrm{~L}^{4 \mathrm{OMe}}\right)(\mathrm{MeOH})\right] \cdot 4,4-\mathrm{bpy}\right)$ Rigaku XtaLAB Synergy diffractometer equipped with Dualflex source and HyPix detector using $\omega$-scans. Data were prepared using the CrysAlis [37] program package. A summary of general and crystal data, intensity data collection, and final refinement parameters are presented in Supplementary Materials Table S3. The structures were solved with dual space methods using SHELXT [38]. The refinement procedure by full-matrix least squares methods based on $F^{2}$ values against all reflections included anisotropic displacement parameters for all non- $\mathrm{H}$ atoms. Hydrogen atoms bound to carbon atoms were placed in geometrically idealized positions and refined by use of the riding model with $U_{\text {iso }}=1.2 U_{\text {eq }}$ of the connected carbon atom or as ideal $\mathrm{CH}_{3}$ groups with $U_{\text {iso }}=1.5 U_{\mathrm{eq}}$. Hydrogen atoms attached to heteroatoms were located in the difference Fourier maps at the final stages of the refinement procedure. Their coordinates were refined freely but with restrained O-H distances of $0.82(2) \AA$. All refinements were performed using SHELXL-2013 [39]. The SHELX programs operated within the Olex2 [40] suite. Geometrical calculations and molecular graphics were done with Mercury [41].

\section{Conclusions}

Oligomeric $\left[\mathrm{MoO}_{2} \mathrm{~L}\right]_{n}$ and monomeric $\left[\mathrm{MoO}_{2} \mathrm{~L}(\mathrm{MeOH})\right]$ molybdenum complexes were prepared by the conventional synthetic procedures, employing DCM or $\mathrm{MeOH}$, as solvents. Formation of oligomeric complexes from monomeric ones could be caused directly through heating. This provided a more convenient synthetic route, eliminating the use of the environmentally harmful DCM solvent. All prepared molybdenum complexes were tested as epoxidation catalysts, with the assistance of TBHP in water or TBHP in decane. For the first time, monomeric and oligomeric complexes showed both excellent activity and selectivity towards epoxide. Similar results were obtained, no matter the oxidant used, giving priority on the use of TBHP in water, in terms of the green process. DFT calculations have extracted trends with this family of complexes rationalizing the experimental values in regard to the ligand structure. Further research will be oriented to the mechanochemical synthesis and solvent-less methods for the complex preparation to respect green chemistry principles. In terms of the catalytic process, improvements will be done towards the use of different model substrates. 
Supplementary Materials: The following are available online at https:/ / www.mdpi.com/article/10 $.3390 /$ catal11070756/s1, Figure S1: Comparison of IR-ATR spectra of the complex [MoO2(L $\left.\mathrm{L}^{3 \mathrm{OMe}}\right)$ $(\mathrm{MeOH})]$ (pink) and [MoO2( $\left.\left.\mathrm{L}^{3 \mathrm{OMe}}\right)\right] n$ (blue). Figure S2: Enumeration of atoms in the crystal structure of $\left[\mathrm{MoO}_{2}\left(\mathrm{~L}^{3 \mathrm{OMe}}\right)(\mathrm{MeOH})\right]$, Figure S3: Enumeration of atoms in the crystal structure of $\left[\mathrm{MoO}_{2}\left(\mathrm{~L}^{4 \mathrm{OMe}}\right)\right.$ $(\mathrm{MeOH})] \cdot 4,4-b p y$, Figure S4: Crystal packing in the crystal structure of $\left[\mathrm{MoO}_{2}\left(\mathrm{~L}^{3 \mathrm{OMe}}\right)(\mathrm{MeOH})\right]$ shown parallel to crystal $a$-axis, Figure S5: Crystal packing in the crystal structure of $\left[\mathrm{MoO}_{2}\left(\mathrm{~L}^{4 \mathrm{OMe}}\right)\right.$ $(\mathrm{MeOH})] \cdot 4,4-b p y$ shown parallel to crystal $b$-axis, Figure S6: Comparison of molecular structures of: (a) and (b) $\left[\mathrm{MoO}_{2}\left(\mathrm{~L}^{3 \mathrm{OMe}}\right)(\mathrm{MeOH})\right]$ (blue) and $\left[\mathrm{MoO}_{2}\left(\mathrm{~L}^{3 \mathrm{OMe}}\right)\left(\mathrm{H}_{2} \mathrm{O}\right)\right]\left(\right.$ grey) ; (c) $\left[\mathrm{MoO}_{2}\left(\mathrm{~L}^{4 \mathrm{OMe}}\right)\right.$ $(\mathrm{MeOH})] \cdot 4,4$-byp (pink) and $(\mathrm{d})\left[\mathrm{MoO}_{2}\left(\mathrm{~L}^{4 \mathrm{OMe}}\right)(\mathrm{MeOH})\right] \cdot \mathrm{MeOH}$ (grey). 4,4-bipyridine and methanol molecules are omitted for clarity. Small variations in crystal composition have a significant effect on complex geometry, Table S1: Geometrical parameters of the octahedral environment of molybdenum atom in the title complexes, Table S2: Bond lengths (in $\AA$ ) and angles (in ${ }^{\circ}$ ) for the prepared complexes. Atom enumeration is shown in Figures S1 and S2, Table S3: Summary of general and crystallographic data for the prepared complexes, Table S4: Simplified images of all the calculated Mo-containing species, Table S5: Imaginary frequency $\left(\mathrm{cm}^{-1}\right)$ of the calculated transition states shown in Table S1, Table S6: DFT Coordinates of all optimized species. CCDC 2085847-2085848 contains the supplementary crystallographic data for this paper. These data can be obtained free of charge from The Cambridge Crystallographic Data Centre via Available online: www.ccdc.cam.ac.uk/structures.

Author Contributions: Conceptualization, J.P. and D.A.; methodology, J.P. and D.A.; validation, S.M., E.T. and M.M.; formal analysis, S.M. and E.T.; investigation, J.P. and D.A.; resources, J.P. and D.A., data curation, J.P. and D.A.; writing—original draft preparation, J.P.; writing—review and editing, J.P., D.A. and E.T.; visualization, E.T., J.P. and D.A.; supervision, J.P. and D.A.; project administration, J.P.; funding acquisition: J.P. and D.A. All authors have read and agreed to the published version of the manuscript.

Funding: This research received no external funding.

Acknowledgments: We acknowledge the support of project CIuK co-financed by the Croatian Government and the European Union through the European Regional Development Fund-Competitiveness and Cohesion Operational Programme (Grant KK.01.1.1.02.0016.). LCC CNRS and IUT Chem Dept. are acknowledged for equipment for the catalysis experiments. LCC and Calmip are acknowledged for the facilities in terms of calculation time. Erasmus+ program supported the internship of $\mathrm{S}$. Mrkonja. The authors acknowledge M. Rubčić and V. Vrdoljak for advices and suggestions during the writing process.

Conflicts of Interest: The authors declare no conflict of interest.

\section{References and Note}

1. Swern, D. (Ed.) Organic Peroxide; Wiley-Interscience: New York, NY, USA, 1971; Volume 2, p. 265.

2. Sheng, M.N.; Cherry Hill, N.J.; Zajaczek, G.J. Molybdenum-containing catalyst and method for the preparation thereof Atlantic Richfield Co. Patent US 3434975A, 25 May 1969.

3. Bregeault, J.M. Transition-metal complexes for liquid-phase catalytic oxidation: Some aspects of industrial reactions and of emerging technologies. Dalton Trans. 2003, 17, 3289. [CrossRef]

4. Sheldon, R.A. Molybdenum-catalysed epoxidation of olefins with alkyl hydroperoxides I. Kinetic and product studies. Recl. Trav. Chim. Pays-Bas 1973, 92, 253-266. [CrossRef]

5. Chong, A.O.; Sharpless, K.B. Mechanism of the molybdenum and vanadium catalyzed epoxidation of olefins by alkyl hydroperoxides. J. Org. Chem. 1977, 42, 1587-1590. [CrossRef]

6. Bhattacharya, P.K. Homogeneous catalysis of epoxidation of olefins by mono- and binuclear Schiff base complexes. J. Chem. Sci. 2008, 102, 247-250.

7. Judmaier, M.E.; Holzer, C.; Volpe, M.; Mösch-Zanetti, N.C. Molybdenum(VI) Dioxo and Oxo-Imido Complexes of Fluorinated $\beta$-Ketiminato Ligands and Their Use in OAT Reactions. Inorg. Chem. 2012, 51, 9956-9966. [CrossRef]

8. Liang, Q.; Newman, P.A.; Daniel, J.S.; Reimann, S.; Hall, B.D.; Dutton, G.; Kuijpers, L.J.M. Constraining the carbon tetrachloride (CC14) budget using its global trend and inter-hemispheric gradient. Geophys. Res. Lett. 2014, 41, 5307-5315. [CrossRef]

9. Hossaini, R.; Chipperfield, M.P.; Montzka, S.A.; Rap, A.; Dhomse, S.; Feng, W. Efficiency of short-lived halogens at influencing climate through depletion of stratospheric ozone. Nat. Geosci. 2015, 8, 186-190. [CrossRef]

10. Byrne, F.P.; Jin, S.; Paggiola, G.; Petchey, T.H.M.; Clark, J.H.; Farmer, T.J.; Hunt, A.J.; McElroy, C.R.; Sherwood, J. Tools and techniques for solvent selection: Green solvent selection guides. Sustain. Chem. Process. 2016, 4, 7. [CrossRef] 
11. Vrdoljak, V.; Pisk, J.; Agustin, D.; Novak, P.; Parlov Vuković, J.; Matković-Čalogović, D. Dioxomolybdenum(VI) and dioxotungsten(VI) complexes chelated with the ONO tridentate hydrazone ligand: Synthesis, structure and catalytic epoxidation activity. New J. Chem. 2014, 38, 6176-6185. [CrossRef]

12. Cvijanović, D.; Pisk, J.; Pavlović, G.; Šišak-Jung, D.; Matković-Čalogović, D.; Cindrić, M.; Agustin, D.; Vrdoljak, V. Discrete monomeric and dinuclear compounds containing a $\mathrm{MoO}_{2}{ }^{2+}$ core and 4-aminobenzhydrazone ligands: Synthesis, structure and organic-solvent-free epoxidation activity. New J. Chem. 2019, 43, 1791-1802. [CrossRef]

13. Pisk, J.; Rubčić, M.; Kuzman, D.; Cindrić, M.; Agustin, D.; Vrdoljak, V. Molybdenum(VI) complexes of hemilabile aroylhydrazone ligands as efficient catalysts for greener cyclooctene epoxidation: An experimental and theoretical approach. New J. Chem. 2019, 43, 5531-5542. [CrossRef]

14. Cindrić, M.; Vrdoljak, V.; Strukan, N.; Kamenar, B. Synthesis and characterization of some mono- and dinuclear molybdenum(VI) thiosemicarbazonato complexes. Polyhedron 2005, 24, 369-376. [CrossRef]

15. Vrdoljak, V.; Cindrić, M.; Milić, D.; Matković-Čalogović, D.; Novak, P.; Kamenar, B. Synthesis of five new molybdenum(VI) thiosemicarbazonato complexes. Crystal structures of salicylaldehyde and 3-methoxy-salicylaldehyde 4-methylthiosemicarbazones and their molybdenum(VI) complexes. Polyhedron 2005, 24, 1717-1726. [CrossRef]

16. Rao, S.N.; Munshi, K.N.; Rao, N.N.; Bhadbhadak, M.M.; Suresh, E. Synthesis, spectral and X-ray structural characterization of $\left[\right.$ cis $\left.-\mathrm{MoO}_{2}(\mathrm{~L})(\mathrm{solv})\right]$ (L=salicylidene salicyloyl hydrazine) and its use as catalytic oxidant. Polyhedron 1999, 18, $2491-2497$. [CrossRef]

17. Jin, N.-Y. Syntheses, crystal structures, and catalytic properties of dioxomolybdenum(VI) complexes with hydrazone ligands. J. Coord. Chem. 2012, 65, 4013-4022. [CrossRef]

18. Jia, X.-C.; Li, J.; Liu, Y.-Y.; Wang, N.; Zhang, H.Z. Kristallogr. New Cryst. Struct. 2013, 228, 179.

19. Wang, W.; Daran, J.-C.; Poli, R.; Agustin, D. OH-substituted tridentate ONO Schiff base ligands and related molybdenum(VI) complexes for solvent-free (ep)oxidation catalysis with TBHP as oxidant. J. Mol. Catal. A Chem 2016, 416, 117-126. [CrossRef]

20. Wang, W.; Guerrero, T.; Merecias, S.R.; García-Ortega, H.; Santillan, R.; Daran, J.-C.; Farfán, N.; Agustin, D.; Poli, R. Substituent effects on solvent-free epoxidation catalyzed by dioxomolybdenum(VI) complexes supported by ONO Schiff base ligands. Inorganica Chim. Acta 2015, 431, 176-183. [CrossRef]

21. Cindrić, M.; Pavlović, G.; Katava, R.; Agustin, D. Towards a global greener process: From solvent-less synthesis of molybdenum(VI) ONO Schiff base complexes to catalyzed olefin epoxidation under organic-solvent-free conditions. New J. Chem. 2017, 41, 594-602. [CrossRef]

22. Chen, G.J.-J.; McDonald, J.W.; Newton, W.E. Synthesis of molybdenum(IV) and molybdenum(V) complexes using oxo abstraction by phosphines. Mechanistic implications. Inorg. Chem. 1976, 15, 2612-2615. [CrossRef]

23. Yu, S.-B.; Holm, R.H. Aspects of the oxygen atom transfer chemistry of tungsten. Inorg. Chem. 1989, 28, 4385-4391. [CrossRef]

24. Lu, J.-F. 4-Hydr oxy-N'-(2-hydroxy-3-methoxybenzylidene)benzohydrazide monohydrate. Acta Crystallogr. Sect. E Struct. Rep. Online 2008, 64, o2032. [CrossRef]

25. Rassem, H.-H.; Salhin, A.; Bin Salleh, B.; Rosli, M.M.; Fun, H.-K. (E)-4-Hydroxy-N'-(2-hydroxy-4-methoxybenzylidene) benzohydrazide. Acta Crystallogr. Sect. E Struct. Rep. Online 2012, 68, o2279. [CrossRef]

26. Salhin, A.; Tameem, A.A.; Saad, B.; Ng, S.-L.; Fun, H.-K. 4-Hydroxy-N'-[(E)-(2-hydroxyphenyl)methylidene]benzohydrazide Acta Crystallogr. Sect. E Struct. Rep. Online 2007, 63, o2880. [CrossRef]

27. Frisch, M.J.; Trucks, G.W.; Schlegel, H.B.; Scuseria, G.E.; Robb, M.A.; Cheeseman, J.R.; Scalmani, G.; Barone, V.; Mennucci, B.; Petersson, G.A.; Nakatsuji, H.; Caricato, M.; Li, X.; Hratchian, H.P.; Izmaylov, A.F.; Bloino, J.; Zheng, G.; Sonnenberg, J.L.; Hada, M.; Ehara, M.; Toyota, K.; Fukuda, R.; Hasegawa, J.; Ishida, M.; Nakajima, T.; Honda, Y.; Kitao, O.; Nakai, H.; Vreven, T.; Montgomery, J.A.; Peralta, J.E.; Ogliaro, F.; Bearpark, M.; Heyd, J.J.; Brothers, E.; Kudin, K.N.; Staroverov, V.N.; Keith, T.; Kobayashi, R.; Normand, J.; Raghavachari, K.; Rendell, A.; Burant, J.C.; Iyengar, S.S.; Tomasi, J.; Cossi, M.; Rega, N.; Millam, J.M.; Klene, M.; Knox, J.E.; Cross, J.B.; Bakken, V.; Adamo, C.; Jaramillo, J.; Gomperts, R.; Stratmann, R.E.; Yazyev, O.; Austin, A.J.; Cammi, R.; Pomelli, C.; Ochterski, J.W.; Martin, R.L.; Morokuma, K.; Zakrzewski, V.G.; Voth, G.A.; Salvador, P.; Dannenberg, J.J.; Dapprich, S.; Daniels, A.D.; Farkas, O.; Foresman, J.B.; Ortiz, J.V.; Cioslowski, J.; Fox, D.J. Gaussian, Inc, Wallingford CT (2013).

28. Becke, D. Density-functional thermochemistry. III. The role of exact exchange. J.Chem. Phys. 1993, 98, 5648-5652. [CrossRef]

29. Lee, C.T.; Yang, W.T.; Parr, R.G. Development of the Colle-Salvetti correlation-energy formula into a functional of the electron density. Phys. Rev. B Condens. Matter Mater. Phys. 1988, 37, 785-789. [CrossRef]

30. Miehlich, B.; Savin, A.; Stoll, H.; Preuss, H. Results obtained with the correlation energy density functionals of becke and Lee, Yang and Parr. Chem. Phys. Lett. 1989, 157, 200-206. [CrossRef]

31. Ditchfield, R.; Hehre, W.J.; Pople, J.A. Self-Consistent Molecular-Orbital Methods. IX. An Extended Gaussian-Type Basis for Molecular-Orbital Studies of Organic Molecules. J. Chem. Phys. 1971, 54, 724-728. [CrossRef]

32. Hehre, W.; Ditchfield, R.; Pople, J. Self-Consistent Molecular Orbital Methods. XII. Further Extensions of Gaussian-Type Basis Sets for Use in Molecular Orbital Studies of Organic Molecules. J. Chem. Phys. 1972, 56, 2257-2261. [CrossRef]

33. Hariharan, P.C.; Pople, J.A. The influence of polarization functions on molecular orbital hydrogenation energies. Theor. Chim. Acta 1973, 28, 213-222. [CrossRef]

34. Hariharan, P.C.; Pople, J.A. Accuracy of AH equilibrium geometries by single determinant molecular-orbital theory. Mol. Phys. 1974, 27, 209-214. [CrossRef] 
35. Stevens, W.J.; Basc, H.; Krauss, M. Compact effective potentials and efficient shared-exponent basis sets for the first- and second-row atoms. J. Chem. Phys. 1984, 81, 6026-6033. [CrossRef]

36. Stevens, W.J.; Krauss, M.; Basch, H.; Jasien, P.G. Relativistic compact effective potentials and efficient, shared-exponent basis sets for the third-, fourth-, and fifth-row atoms. Can. J. Chem. 1992, 70, 612-630. [CrossRef]

37. Rigaku Oxford Diffraction. CrysAlisPro. Version 1.171.39.46e; Rigaku Oxford Diffraction: The Woodlands, TX, USA, 2018.

38. Sheldrick, G.M. SHELXT-Integrated space-group and crystal-structure determination. Acta Cryst. 2015, A71, 3-8. [CrossRef] [PubMed]

39. Sheldrick, G.M. Crystal structure refinement with SHELXL. Acta Cryst. 2015, C71, 3.

40. Dolomanov, O.V.; Bourhis, L.J.; Gildea, R.J.; Howard, J.A.K.; Puschmann, H.J. OLEX2: A complete structure solution, refinement and analysis program. Appl. Cryst. 2009, 42, 339-341. [CrossRef]

41. Groom, C.R.; Bruno, I.J.; Lightfoot, M.P.; Ward, S.C. The Cambridge structural database. Acta Cryst. 2016, B72, 171. [CrossRef] 